\title{
New insights into the life-history of the isopod Edotia dahli (Valvifera: Idoteidae): report of host-use and distribution records in the central Chilean coast
}

Nuevos antecedentes en la historia de vida del isópodo Edotia dahli (Valvifera: Idoteidae): reporte de uso de hospedador y registros de distribución en la costa central de Chile

\section{Sergio A. Carrasco ${ }^{1}$, Osvaldo Cerda $^{2}$ and Mauricio Cifuentes ${ }^{1,3}$}

\author{
${ }^{1}$ School of Biological Sciences and Coastal Ecology Laboratory, Victoria University of Wellington, Wellington 6140, New \\ Zealand. scarrasco.o@gmail.com \\ ${ }^{2}$ Center for Advanced Studies in Arid Zones (CEAZA) and Universidad Católica del Norte, Larrondo 1281, Coquimbo, Chile \\ ${ }^{3}$ Facultad de Ciencias del Mar, Universidad Católica del Norte, Larrondo 1281, Coquimbo, Chile
}

\begin{abstract}
Unreported aspects of the life-history of the isopod Edotia dahli are described based on intertidal collections carried out during 2002, 2005 and 2011 in 5 locations in central Chile (29-33 S; Pacific coast). Isopods were recorded for the first time living on 2 species of echinoderms, the sea-star Heliaster helianthus and the sea-urchin Arbacia sp. The observation of sea-urchins hosting isopods was casual (i.e., no formal samplings); however, nearly $20 \%$ of the sampled sea-stars hosted isopods (from 2 to $>100$ individuals per host). This association was similar through years. Surveys also revealed that $E$. dahli was present at higher latitudes than those previously recorded in the central Chilean coast, extending the northern distribution range $3^{\circ}$ to $29^{\circ} \mathrm{S}$.
\end{abstract}

Key words: Idoteidae, inter-specific associations, Heliaster helianthus, Arbacia sp.

\section{INTRODUCTION}

Isopods of the family Idoteidae Fabricius, 1798 are common inhabitants of rocky shores worldwide. Some genera typically dwell on brown algae (e.g., Calidotea, Erichsonella, Eusymmerus and Idotia; reviewed by Stebbins 1989), whereas others have been reported living in association with echinoderms (e.g., Colidotea; Stebbins 1988) and mollusks (e.g., Edotia; Jaramillo et al. 1981, González \& Jaramillo 1991, Gray et al. 1997, Zaixso et al. 2009).

Species of the genus Edotia Guérin-Méneville, 1844 are predominantly found in the Southern hemisphere, with 13 of the 19 known species recorded in temperate and cold waters (Brandt \& Bruce 2006). Of those, six species have been recorded in the Chilean coast (i.e., 32-56 ${ }^{\circ}$; $E$. chilensis, E. dahli, E. doellojuradoi, E. magellanica, E. transversa and E. tuberculata; see Menzies 1962 and González et al. 2008 for details); however, only a few studies have examined the life-history and ecology of this genus in these latitudes (e.g., Jaramillo et al. 1981,
González \& Jaramillo 1991). In fact, most Edotia spp. from Chilean waters have been described as free-living species, inhabiting coarse sand, rocks and small stones from 1 to $100 \mathrm{~m}$ depth (Menzies 1962, SEMAR 2005ํㅗ IFOP 2009²). To date, the studies of Jaramillo et al. (1981), González \& Jaramillo (1991), and Zaixso et al. (2009), are the only field-based observations describing inter-specific associations between the idoteids E. magellanica and $E$. doellojuradoi, and their host bivalves, Mytilus chilensis and Mulina edulis, on the southeast Pacific coast.

Unlike those species, Edotia dahli has only been described as free living, inhabiting soft bottoms or hard substrata such as rocks or small stones (Menzies 1962, Ríos et al. 2003, SEMAR 2005', IFOP 2009²). However, our preliminary surveys showed the presence of this isopod living in association with the widely distributed sea-star Heliaster helianthus Lamarck, 1816 (hereafter Heliaster) in intertidal locations of the Chilean coast.

${ }^{1}$ SEMAR 2005. Anexo VIII, Estudio bentónico. Estudio bentónico Bahía de Coronel. Sistema de disposición final de riles de la industria pesquera de la región del Bio-Bío. Declaración de Impacto Ambiental (DIA), 5058-09.8-03.III-08-REP-01-B: 1-23. SEMAR LTDA. [en línea] <https://www.e-seia.cl/archivos/Anexo_VIII_Estudio_Betonico.pdf>

${ }^{2}$ IFOP. 2009. Macrofauna bentónica de Chile. Compendio de claves taxonómicas, Instituto de Fomento Pesquero, Valparaíso. [en línea] <http://www.macrofauna.cl/nav_crustaceos.html> 
Between-species associations, whether resulting in beneficial (mutualism), neutral (commensalism) or detrimental (parasitism) interactions are relatively common in nature, and the fitness outcome for the organisms involved can have major ecological and/or evolutionary consequences (Leung \& Poulin 2008). However, in order to quantify ecological and/or evolutionary consequences of between species associations, the host use pattern must first be rigorously documented (Baeza \& Díaz-Valdés 2011). Here, we document for the first time the presence of the isopod Edotia dahli living on 2 species of echinoderms, the sea-star Heliaster and the sea urchin Arbacia sp. (hereafter Arbacia Gray, 1835). Specifically, we aimed to: (1) provide the first observations of E. dahli living in association with these 2 echinoderms, and particularly with Heliaster at different spatial and temporal scales, and (2) expand upon current knowledge of the distributional limits of E. dahli on the Pacific coast of Chile.

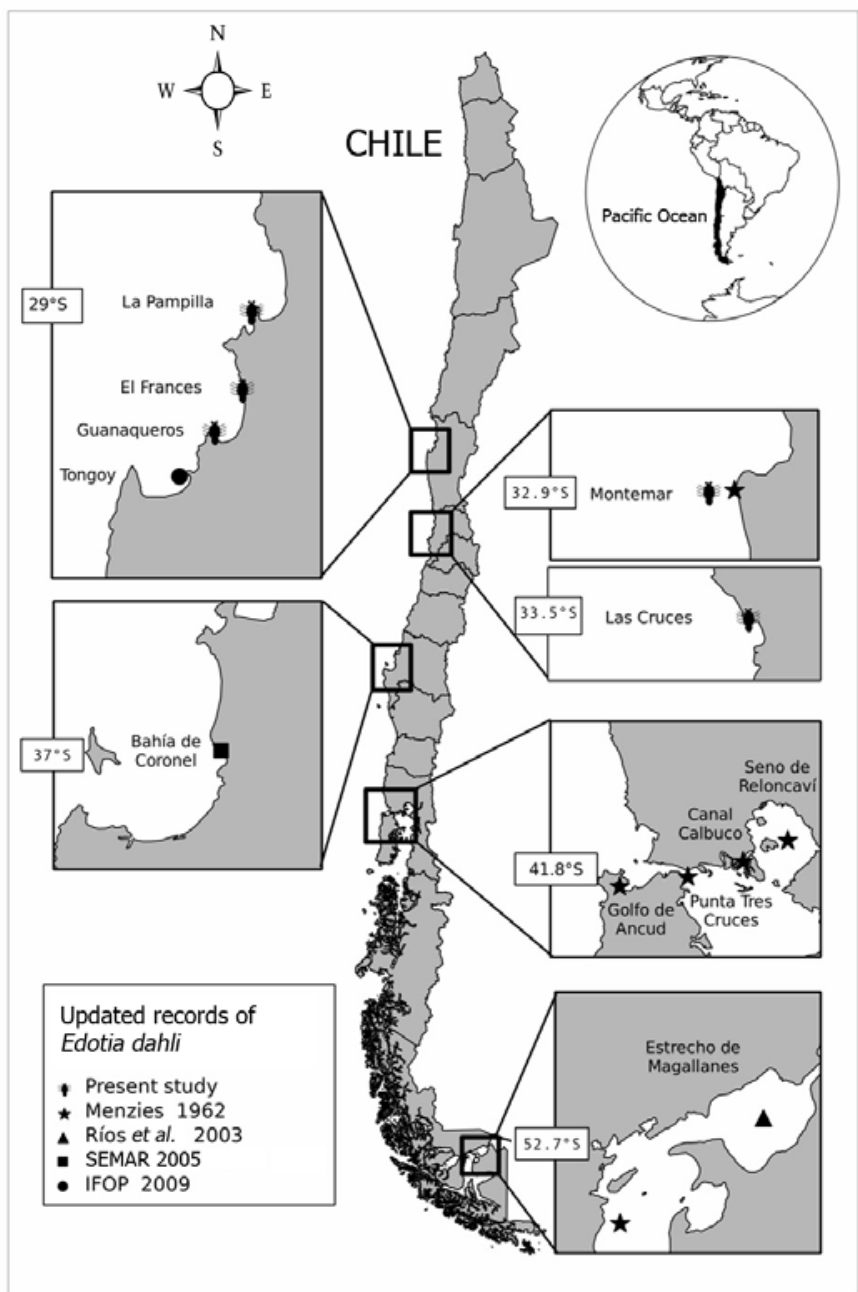

\section{Materials ANd Methods}

Intertidal field surveys were carried out during different years and locations along the Chilean coast $\left(29^{\circ}-33^{\circ} \mathrm{S}\right)$ : La Pampilla (October 2002, December 2011), El Frances (October 2002), Las Cruces (January 2005), Guanaqueros (May 2011) and Montemar (June 2011) (Fig. 1). Each location was surveyed in just one site and only once per year. In each sampling site, all Heliaster within a $20 \mathrm{~m}$ stretch of coast (mid-intertidal) were hand collected, measured (diameter, $\mathrm{cm}$ ), and visually examined for the presence of Edotia dahli. Generally, an average number of $\sim 30$ Heliaster specimens were surveyed at each site. When the isopods were associated with the sea-stars, several individuals were collected and preserved in $70 \%$ ethanol for further examination. Isopods were measured in the laboratory, i.e., length $(\mathrm{L}, \mathrm{mm})$ and width $(\mathrm{W}, \mathrm{mm})$, using a dissecting microscope equipped with an ocular micrometer at $20 \mathrm{X}$ magnification.
Figure 1. Updated records of the isopod Edotia dahli along the Southeast Pacific coast (Chile) / Registros actualizados del isópodo Edotia dahli a lo largo de la costa Sureste del Pacífico (Chile) 


\section{Results AND Discussion}

We observed Edotia dahli living in close association with individuals of the sea-star Heliaster in all sampling locations (Fig. 1), and also with three sea-urchins identified as Arbacia sp. in Montemar (2002; Fig. 1). We considered this encounter casual as the sampling did not aim to record the association between Arbacia sp. and E. dahli, and no formal samplings were further undertaken. All the isopods presented the typical characteristics of E. dahli (see Menzies 1962; Fig. 2a), with a projecting and pointed frontal lamina (Fig. 2b), the dorsum of the head with a medial bilobate elevation, small and laterally situated eyes and laterally protruding coxal plates. Pereopods were relatively large with two distal claws in the dactylus (Fig. 2c). The dorsal claw was larger than the ventral one (Fig. 2d). The specimens of E. dahli collected across years and sampling locations varied in size from 1.88 to $6.48 \mathrm{~mm}$ in length $(4.23 \pm 0.99 \mathrm{~mm}$ [mean $\pm \mathrm{SD}])$ and from 0.67 to $2.81 \mathrm{~mm}$ in width $(1.71 \pm 0.47 \mathrm{~mm}$ [mean \pm SD] ) (Fig. 2).

The isopods were always located on the oral surface of the host's body. In Heliaster they were positioned in the arms and deeply embedded among the ambulacral podia, sometimes distinguishable only by the branchial chamber enclosing the pleopods (typical of valviferan isopods, Poore 2001) which extends out perpendicular to the body axis (Fig. 3a). In Arbacia, isopods were located around the peristomal membrane next to the Aristotle's lantern (Fig. 3b). The color of the isopods varied, depending on the background of the host species, i.e., yellowish in Heliaster and dark-red in Arbacia (Fig. 3a, b). This is not surprising since almost all idoteids are cryptic species that closely match the color of the substrate they occupy (Stebbins 1989).

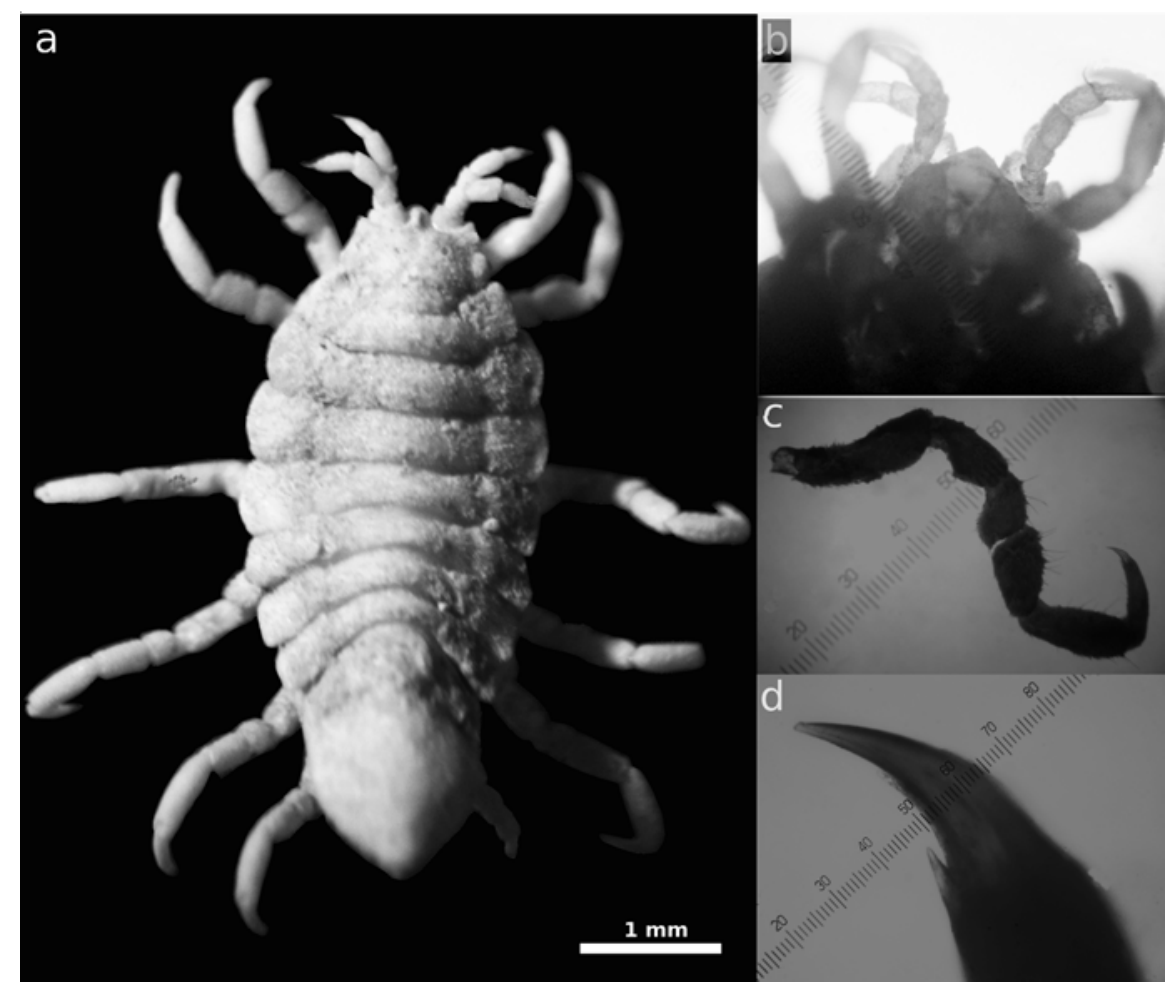

Figure 2. Individual Edotia dahli (4.5 $\mathrm{mm}$ length and $2 \mathrm{~mm}$ width), a) dorsal view of complete specimen, b) ventral view of frontal lamina projecting and pointed, c) pereopod, and d) distal claw in the dactylus / Individuo Edotia dahli (4,5 $\mathrm{mm}$ largo and $2 \mathrm{~mm}$ ancho), a) vista dorsal del espécimen completo, b) vista ventral de la lámina frontal prominente y puntiaguda, c) pereiópodos, y d) quela distal en el dáctilo 


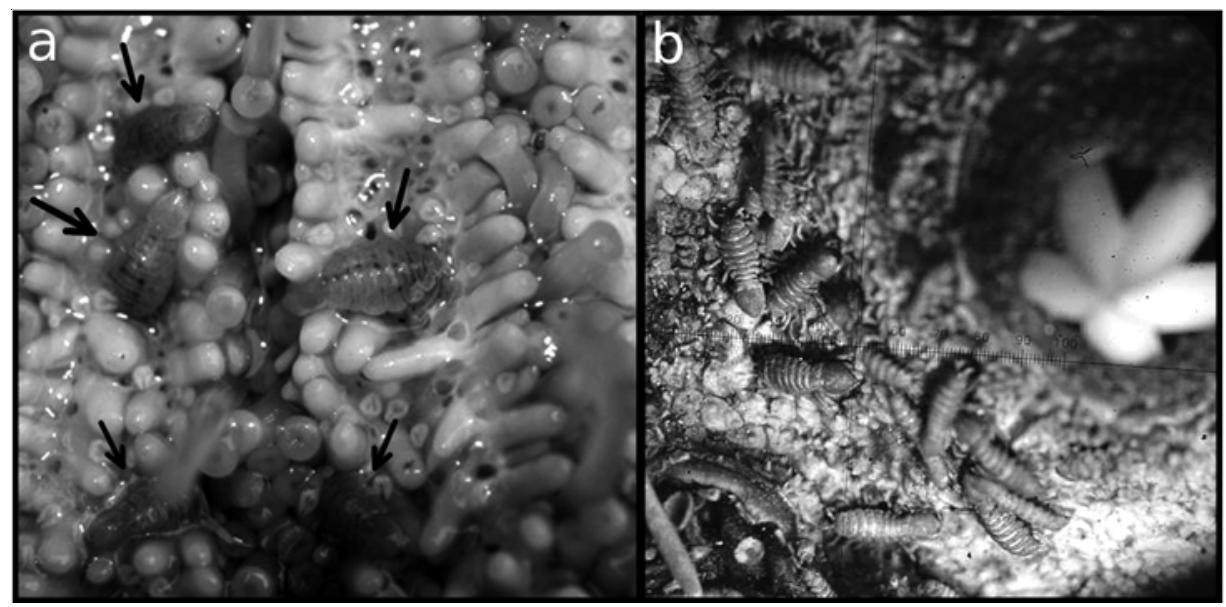

Figure 3. Edotia dahli and its host species on an oral view: a) the sea-star Heliaster helianthus and b) the sea-urchin Arbacia sp. / Edotia dahli y sus hospedadores en una vista oral: a) sol de mar Heliaster helianthus y b) erizo de mar Arbacia sp.

The prevalence of the association between Edotia dahli and Heliaster was similar across years and sites, with nearly $20 \%$ of the sea-stars sampled per year-site combination ( $\mathrm{n}=\sim 30$ individuals of $H$. helianthus sampled per site; mean body size: $18.7 \pm 3.2 \mathrm{~cm}$ diameter) hosting between 2 to $>100$ isopods per host (mean body size: $4.2 \pm 0.9 \mathrm{~mm}$ length). The few published studies that have included idoteid isopods of the Chilean coast have typically described $E$. dahli as a free living organism, inhabiting soft bottoms or hard substrata such as rocks or small stones (Menzies 1962, Ríos et al. 2003, SEMAR $2005^{1}$, IFOP 2009²). In those studies however, the use of dredges as a sampling method might decrease the chances of accurately obtain information about the natural history of the organisms collected, since isopods could accidentally be detached from their hosts. To date, this study is the first direct evidence of an association between the isopod E. dahli with one host species (i.e., Heliaster), and a possible association with another (i.e., Arbacia). Although the association with Arbacia may be considered a casual record, this needs further consideration, since multi-host use patterns have also been previously observed in other isopods of the same genus, such as $E$. magellanica associated with the bivalves Mytilus chilensis (Jaramillo et al. 1981) and Mulina edulis (Gonzalez \& Jaramillo 1991) and E. doellojuradoi with their hosts Mytilus edulis platensis (Zaixso et al. 2009) and Mytilus chilensis (Gray et al. 1997).

As we found Edotia dahli at La Pampilla $\left(29^{\circ} \mathrm{S}\right)$, the most northern location surveyed in this study, it is likely that the true northern limit in the distribution of E. dahli is further north (Fig. 1). The available literature reports that $E$. dahli is distributed between $32^{\circ} \mathrm{S}$ to $50-54^{\circ} \mathrm{S}$ (Menzies 1962, Brandt \& Bruce 2006, González et al. 2008) and therefore, this record extends the distributional range of the species by approximately $400 \mathrm{~km}$ from the most northern locality (Montemar, $32^{\circ} \mathrm{S}$ ) originally described by Menzies (1962) and $40 \mathrm{~km}$ from a later record (Tongoy, $30^{\circ} \mathrm{S}$ ) by Instituto de Fomento Pesquero (IFOP), Chile (IFOP 2009²) (see Fig. 1 for updated records). Because no exhaustive samplings were performed further north, we suggest that other locations where this association might be found still remain to be added to the northern distributional record of the species. Additionally, since the southern distribution of the host species Heliaster is up to $33^{\circ} \mathrm{S}$ (Tokeshi et al. 1989), it is likely that E. dahli can be associated with other host species, explaining in part its southern distribution. As we found here, possible hosts may include sea-urchins of the genus Arbacia, which are known to inhabit the central and southern Chilean coast (e.g., A. dufresni and A. spatuligera; Lessios et al. 2012).

The existence of the consistent and in some cases stable association between Edotia dahli and the seastar Heliaster, i.e., population from La Pampilla sampled in 2002 and 2011, in addition to the reduced motility and cryptic nature of the isopods collected, suggest that this could be an obligate association. Although the boundary among mutualism, commensalism and parasitism is often difficult to identify without the appropriate knowledge, studies on other idoteids have found clear evidences of commensalism and parasitism [e.g., Colidotea rostrata, a sea urchin-dwelling from southern California (Stebbins 1988) and E. doellojuradoi, a mussel-dwelling from Argentinean Patagonia and southern Chile (Zaixso et al. 2009)]. Similar to the findings of those studies, we observed that individuals of $E$. dahli were not able to swim or walk effectively when detached from the host 
sea-stars and placed upon glass surfaces or small stones (M. Cifuentes, pers. obs.). Interestingly, isopods in different life stages, i.e., males, females, ovigerous females and juveniles were also found on single host individuals (M. Cifuentes, unpublished data), suggesting that a combination of factors such as low autonomous potential for dispersal, extended parental care, local recruitment and host complexity, may contribute to the high number of isopods found in some Heliaster (see Thiel 2003 and Baeza \& Díaz-Valdés 2011, for examples). In our field-based observations we were unable to detect any detrimental effect of $E$. dahli on their host species. However, some individuals of Heliaster hosting more than 100 isopods seem to lack the typical body turgidity observed in individuals with just a few or no isopods at all. This observation however, has not been empirically supported and further experimental trials are needed in order to explore possible detrimental effects on the host species.

This report is a first step towards a better understanding of the life-history of the southeast Pacific idoteid Edotia dahli. However, we also highlight other interesting questions that remain to be evaluated, such as a probable correlated distribution between the isopods and its hosts, and the possible exchange of isopods across host species during predatory encounters of the endemic South American sea-star $H$. helianthus with both predators (e.g., the sea-star Meyenaster gelatinosus) or prey (e.g., the sea-urchins Arbacia sp., and Tetrapygus niger).

\section{AcKnowledgments}

The authors would like to thank Martin Thiel for his guidance during initial identification of specimens collected. Nelson Vásquez and Jorge Varela for their assistance during field surveys. Alejandro Pérez-Matus assisted us with the pictures of $H$. helianthus sampled at Montemar. The comments of Nicole Phillips, Andrea Varela and Shane Geange greatly improved preliminary versions of the manuscript.

\section{LITERATURE CITED}

Baeza JA \& M Díaz-Valdés. 2011. The symbiotic shrimp Ascidonia flavomaculata lives solitary in the tunicate Ascidia mentula: implications for its mating system. Invertebrate Biology 130(4): 351-361.

Brandt A \& N Bruce. 2006. Edotia tangaroa sp. nov. (Crustacea: Isopoda: Idoteidae) from the western Ross Sea, Antarctica. Zootaxa 1313: 57-68.
González M \& E Jaramillo. 1991. The association between Mulina edulis (Mollusca: Bivalvia) and Edotea magallanica (Crustacea: Isopoda) in Southern Chile. Revista Chilena de Historia Natural 64: 37-51.

González ER, PA Haye, MJ Balanda \& M Thiel. 2008. Lista sistemática de especies de peracáridos de Chile (Crustacea: Eumalacostraca). Gayana 72(2):157-177.

Gray AP, CA Richardson \& R Seed. 1997. Ecological relationships between the valviferan isopod Edotia doellojuradoi Giambiagi, 1925, and its host Mytilus edulis chilensis in the Falkland Islands. Estuarine, Coastal and Shelf Science 44: 231-239.

Jaramillo E, J Navarro \& J Winter. 1981. The association between Mytilus chilensis Hupe (Bivalvia: Mytilidae) and Edotea magellanica Cunningham (Isopoda: Valvifera) in southern Chile. The Biological Bulletin 160: 107-113.

Lessios HA, S Lockharts, R Collin, G Sotil, P SanchezJerez, KS Zigler, AF Pérez, MJ Garrido, LB Geyer, G Bernardi, VD Vacquier, R Haroun \& BD Kessing. 2012. Phylogeography and bindin evolution in Arbacia, a sea urchin genus with an unusual distribution. Molecular Ecology 21(1): 130-144.

Leung TLF \& R Poulin. 2008. Parasitism, commensalism, and mutualism: exploring the many shades of symbioses. Vie et Milieu 58(2): 107-115.

Menzies RJ. 1962. The zoogeography, ecology, and systematics of the Chilean marine isopods. Reports of the Lund University Chile Expedition 1948-49. 42. Lund Universitets Ärsskrifter NF Avdelningen 2(57): 1-62.

Poore GCB. 2001. Isopoda Valvifera: Diagnoses and relationships of the families. Journal of Crustacean Biology 21: 205-230.

Ríos C, E Muetschke \& E Morrison. 2003. Biodiversidad bentónica sublitoral en el estrecho de Magallanes, Chile. Revista de Biología Marina y Oceanografía 38(1): 1-12.

Stebbins TD. 1988. Observation and experiments on the natural history and behavior of the commensal isopod Colidotea rostrata (Benedict, 1898) (Isopoda: Idoteidae). Journal of Crustacean Biology 8(4): 539-547.

Stebbins TD. 1989. Population dynamics and reproductive biology of the commensal isopod Colidotea rostrata (Crustacea: Isopoda: Idoteidae). 1989. Marine Biology 101: 329-337.

Thiel M. 2003. Reproductive biology of Limnoria chilensis: another boring peracarid species with extended parental care. Journal of Animal Ecology 37(14): 1713-1726.

Tokeshi M, M Estrella \& C Paredes. 1989. Feeding ecology of a size-structured predator population, the South American sun-star Heliaster helianthus. Marine Biology 100: 495-505.

Zaixso HE, PD Stoyanoff \& G Gil. 2009. Detrimental effects of the isopod, Edotia doellojuradoi, on gill morphology and host condition of the mussel, Mytilus edulis platensis. Marine Biology 156: 2369-2378. 